\title{
Clinical Results of Surgical Management in Type II Odontoid Fracture: A Preliminary Report
}

\section{Tip II Odontoid Kurıta CerrabiTedavinin Klinik Sonuçları: Ön Rapor}

\author{
Hossein MASHHADINEZHAD ${ }^{1}$, Fariborz SAMINI ${ }^{1}$, Ali MASHHADINEZHAD ${ }^{1}$, Ali BIRJANDINEJAD ${ }^{2}$ \\ ${ }^{1}$ Mashbad of University Medical Science, Trauma Research Center, Shabid Kamyab Hospital, Department of Neurosurgery, Mashhad/Khorasan \\ Razavi, Islamic Republic of Iran \\ ${ }_{2}^{2}$ Mashhad of University Medical Science, Trauma Research Center, Shahid Kamyab Hospital, Department of Orthopedic Surgery, Mashbad/ \\ Khorasan Razavi, Islamic Republic of Iran
}

Presented in: International Conference on Spinal Cord Medicine \& Rehabilitation, 2011 Washington D. C, USA

Correspondence address: Fariborz SAMINI / E-mail: Saminif@Mums.ac.ir

\begin{abstract}
AIM: This study was conducted to evaluate the therapeutic effectiveness of surgical approaches in type II odontoid fracture.

MATERIAL and METHODS: In a retrospective study in Mashhad university, 15 patients with anterior screw fixation technique (ASF) and 31 patients with posterior approaches (PA) were reviewed. Patient demographics, clinical presentation, length of hospital stay, operation time, injury severity score (ISS), Preinjury Charlson comorbidity index, fusion rate and surgical complications were analyzed in these two groups.

RESULTS: Neck pain was the most common clinical presentation in these two groups (89.7\%). There were no significant differences in ISS and mean length of hospital stay and Comorbidity index between the two groups. The operation time was different between these two groups (65 minutes in ASF versus 118 minutes in PA, $\mathrm{P}<0.05)$. Bone union was documented in 13 patients (87\%) with ASF and 28 patients (90\%) with PA.

CONCLUSION: The outcome of surgery with anterior or posterior approach in the patients are potential candidates for surgery is good. In our patients, the operation time is different in the two groups but differences in fusion rate, length of hospital stay, comorbidity index and postsurgical complications are not considerable.
\end{abstract}

KEYWORDS: Type II odontoid fracture, Surgical management, Anterior approach, Posterior approach

Öz

AMAÇ: Bu çalışma tip II odontoid kırıklarda cerrahi yaklaşımın terapötik etkinliğini değerlendirmek için yapıldı.

YÖNTEM ve GEREÇLER: Mashhad Üniversitesinde yapılan retrospektif bir çalışmada anterior vida fiksasyon tekniği (ASF) kullanılan 15 hasta ve posterior yaklaşımlar (PA) kullanılan 31 hasta gözden geçirildi. Bu iki grupta hasta demografik bilgileri, klinik sunum, hastanede kalma süresi, operasyon süresi, yaralanma şiddeti skoru (ISS), yaralanma öncesi Charlson Komorbidite İndeksi, füzyon oranı ve cerrahi komplikasyonlar analiz edildi.

BULGULAR: Bu iki grupta en sık görülen klinik sunum boyun ağrısıydı $(\% 89,7)$. İki grup arasında ISS ve ortalama hastanede kalma süresi ile komorbidite indeksi arasında önemli fark yoktu. Operasyon süresi bu iki grup arasında farklıydı (ASF grubunda 65 dakika ve PA grubunda 118 dakika, $\mathrm{P}<0,05)$. Kemik birleşmesi ASF'li 13 hastada (\%87) ve PA'lı 28 hastada (\%90) görüldü.

SONUÇ: Cerrahi için uygun olan hastalarda anterior veya posterior yaklaşımla cerrahi sonuçları iyidir. Hastalarımızda operasyon süresi iki grupta farklıydı ama füzyon oranı, hastanede kalma süresi, komorbidite indeksi ve cerrahi sonrası komplikasyonlar açısından önemli fark yoktu.

ANAHTAR SÖZCÜKLER: Tip II odontoid kırığı, Cerrahi tedavi, Anterior yaklaşım, Posterior yaklaşım

\section{INTRODUCTION}

Odontoid fractures are the most common type of axis fracture. According to Anderson-D'Alonzo classification (2), type II odontoid fractures in which the fracture line passes the base of the odontoid are the most common type. A subtype of type II (IIA) is thought to be unstable. External immobilization or surgical fixation can be used to stabilize these fractures but conservative treatment has failed in many patients to achieve a satisfactory fusion. A variety of surgical approaches including an anterior or a posterior approach described for the upper cervical spine $(3,11,19)$.

Several posterior approaches, such as $\mathrm{C} 1-\mathrm{C} 2$ posterior wiring and fusion, C1-C2 transarticular screw stabilization and posterior clamping techniques were used to stabilize the C1-C2 complex. Despite excellent stability with these approaches, they eliminate the normal atlantoaxial rotatory motion $(5,15,20)$. In contrast, anterior screw fixation was introduced to provide immediate stabilization with preserving 
atlantoaxial motion $(8,9)$. In recent years, there has been an increasing tendency toward using anterior screw fixation in management of type II odontoid fractures (11).

The decision for the optimal treatment could be difficult in a patient with acute type II odontoid fracture that could be treated with either an anterior or posterior approach. Anterior screw fixation has been recently used in our trauma centers. This provided a chance for us to compare retrospectively clinical results of patients underwent anterior screw fixation with patients underwent posterior approaches who were also potential candidates for anterior screw fixation.

\section{MATERIAL and METHODS}

Between March 2005 and March 2010, fifty seven patients were identified with acute type II odontoid fractures that were managed surgically in the neurosurgical units of academic trauma hospitals in Mashhad university medical sciences, Mashhad, Iran. Our inclusion criteria were: patients with at least a 9-month follow-up after surgery, patient older than 18 years, non-pathological type II odontoid fracture, patients with unstable type II odontoid fracture who were potential candidates for both approaches, and the time of the surgery less than 30 days after the injury.

Our contraindications for anterior screw fixation were disruption of transverse atlantal ligament, fractures that comminuted or slope obliquely and anteriorly, thoracic kyphosis associated with limited cervical spine extension, and Presence of severe spondylosis with spinal canal narrowing. Excluding three patients who had insufficient follow-up period and lacked the follow-up documents and eight patients with posterior fixation approaches who had contraindication for anterior screw fixation, forty six patients were reviewed in this study. Choosing one approach was based on surgeon experience and preference. Out of 46 patients, anterior screw fixation was performed in 15 cases and posterior fixation technique in 31. Preoperative evaluations were lateral, AP plain and open-mouth X-ray films. Computed tomographic scans were performed in 36 patients. In 9 month follow up, plain x-ray films with flexion /extension views were carried out to assess the bony fusion. Patient hospital records were reviewed for age, sex, mechanism of injury, presence of neurological symptoms at the time of hospital admission ,length of hospitalization, length of ICU stay, the time of surgery after the injury, duration of the operation, injury severity score (ISS), preinjury Charlson comorbidity index $(\mathrm{CCl})$ and surgical procedures. The $\mathrm{CCl}$ was scored from International Classification of Diseases Tenth Revision (ICD-10) according to hospital records. The comparison of these factors was made between anterior screw fixation and posterior approaches. Bony fusion was confirmed if we found bony trabeculation crossing the fracture site, absence of motion on flexion/extension views, and absence of sclerotic borders adjacent to the fracture site. CT scans were used in three patients to confirm bone fusion.
Statistical analysis was performed with SPSS 18 software (SPSS Inc., Chicago, Illinois). The results were represented as mean \pm standard deviation. Differences between continuous variables were assessed by the T-test. $P$ values less than 0.05 were considered to be statistically significant.

\section{RESULTS}

\section{Demographics, mechanism of injury}

Out of 46 patients, 33 were men and 13 were women with mean age of $33 \pm 12.6$ SD. (range $18-75$ ). Table I shows the mechanism of injury of the type II odontoid fracture suffered by our patients. They included motor vehicle accident (65.2\%) in the vast majority, followed by falls from a height $(28.3 \%)$ and, to a much lesser extent, fight (6.5\%).

\section{Neurological symptoms, Time of surgery}

Table Il summaries the neurological symptoms in our patients on admission to hospital. The most common neurological symptom in these patients was neck pain (89\%). Surgery was performed between 3 and 14 days after trauma (Mean $6 \pm 2.7$ days).

Length of hospitalization, Injury severity score (ISS), Charlson comorbidity score (CCI)

The mean length of hospitalization was 14 days ( \pm 5.5 SD. The mean ISS was 7.5 ( \pm 6 SD) and the mean $\mathrm{CCl}$ was 0.69 ( $\pm 1.2 \mathrm{SD})$. There was not a correlation between length of hospitalization and ISS $(r=0.34, n=46, P=0.06)$ or $C C I(r=0.1$, $\mathrm{n}=46, \mathrm{P}=0.57)$.

\section{Comparison of anterior screw fixation (ASF) and posterior approaches (PA)}

Posterior approaches were applied to patients including 15 patients with $\mathrm{C} 1-\mathrm{C} 2$ posterior wiring, 13 patients with $\mathrm{C} 1-\mathrm{C} 2$ transarticular screw, and 3 patients with posterior clamping techniques. Table III shows the comparison between anterior screw fixation (ASF) and posterior approaches (PA) patients. Mean duration of surgery was $65( \pm 3.2 \mathrm{SD})$ in the ASF group and $118( \pm 2.7 \mathrm{SD})$ in the PA group. There was statically significant difference in duration of surgery between these two groups $(P<0.05)$. There was no statically significant difference in age, length of hospitalization, length of ICU stay, ISS, and CCI between these two groups.

\section{Bone union, procedure-related Complication}

Among patients who underwent anterior screw fixation, 13 patients (87\%) achieved bony union and showed a normal range of cervical motion at the nine month follow-up. Two patients who did not develop a bone fusion was treated operatively with C1-C2 posterior screw fixation. Among patients who underwent posterior approaches, 28 patients (90\%) achieved bony union. Two patients were treated as malunion (6.4\%) and nonunion developed in one patient (3.2\%). During follow-up, neither procedure-related death nor complications related to surgical exposure were observed in our patients. After surgery, no patient suffered deterioration 
Table I: Mechanism of Trauma in Our Patients with Type II Odontoid Fracture

\begin{tabular}{|l|c|c|}
\hline Mechanism of injury & Percentage & Patient no. \\
\hline Motor vehicle accident & 65.2 & $30 / 46$ \\
\hline Fall & 28.3 & $13 / 46$ \\
\hline Fight & 6.5 & $3 / 46$
\end{tabular}

Table II: Neurological Symptoms in Our Patients with Type II Odontoid Fracture

\begin{tabular}{|l|c|c|}
\hline Neurological symptoms & Percentage & Patient no. \\
\hline Neck pain & 89 & $41 / 46$ \\
\hline Restricted neck motion & 78 & $36 / 46$ \\
\hline Weakness in arms & 19.5 & $9 / 46$ \\
\hline Quadriparesis & 6.5 & $3 / 46$ \\
\hline Torticollis & 4.3 & $2 / 46$
\end{tabular}

Table III: The Comparison Between Anterior Screw Fixation and Posterior Approaches in Our Patients with Type II Odontoid Fracture

\begin{tabular}{|l|c|c|c|}
\hline & Anterior screw fixation & Posterior approaches & P - value \\
\hline Gender & $4 \mathrm{~F}, 11 \mathrm{M}$ & $9 \mathrm{~F}, 22 \mathrm{M}$ & - \\
\hline Age (years) & $31( \pm 8.8)$ & $34.5( \pm 14)$ & $\mathrm{P}=0.49$ \\
\hline Length of hospitalization (day) & $13( \pm 1.7)$ & $15( \pm 6.4)$ & $\mathrm{P}=0.29$ \\
\hline Length of ICU stay (day) & $0.89( \pm 1.3)$ & $1.1( \pm 2.1)$ & $\mathrm{P}=0.83$ \\
\hline Injury severity score & $7( \pm 4.1)$ & $7.75( \pm 7)$ & $\mathrm{P}=0.77$ \\
\hline Charlson comorbidity index & $0.22( \pm 0.44)$ & $0.9( \pm 1.4)$ & $\mathrm{P}=0.25$ \\
\hline Duration of surgery * & $65( \pm 3.2)$ & $118( \pm 2.7)$ & $\mathbf{P = 0 . 0 0 2}$ \\
\hline Bone union & $87 \%$ & $90 \%$ & - \\
\hline
\end{tabular}

*Duration of surgery in minutes.

of neurological function. Only one patient had urinary tract infection after surgery which treated with antimicrobial drugs. Two of the three patients with pre-operative quadriparesis showed neurological improvement but one of them was unable to ambulate without assistance at 9-month follow-up.

\section{DISCUSSION}

The mechanism of type II odontoid fracture is variable, including hyperflexion, hyperextension, lateral flexion and a combination (10). As this type of fracture has a relatively high risk of nonunion, the appropriate treatment of type ll odontoid fractures has been the subject of many investigations but still remains a matter of debate $(16,17,19)$. Although external immobilization with halo vest has been used for treatment of acute type II fractures, the nonunion rates have been unacceptably high especially in elderly patients $(13,15)$. Therefore, surgical techniques have developed to improve the union rate $(9,12)$. Surgical fixation was especially considered as an option in cases of dens displacement of $5 \mathrm{~mm}$ or more, comminuting of the odontoid fracture (type IIA), inability to achieve or maintain fracture alignment with external immobilization, and in elderly patients (19).

Surgical fixation can be performed anteriorly or posteriorly. In posterior approach C1-C2 wiring, clamping techniques, C1-C2 transarticular or pars interarticular screw has been described and union rates after use these approaches to be excellent in several reports $(5,15,16)$. Posterior approaches have serious disadvantages, they eliminate normal rotatory motion of the atlantoaxial complex and restrict flexion/extension of the cervical spine $(4,15,22)$.

In anterior approach, anterior odontoid screw fixation with one or two screws is performed. It has become more prevalent in the past three decades. Numerous papers have been published on fusion rate and complications of this procedure $(1,14)$.

There are few comparative studies exist to recommend one method of treatment over another $(3,13)$. Heterogeneity in these studies especially in patients' selection, co-morbidity, and age makes it difficult to compare the results between these studies. Most of these studies compared these two surgical approaches in elderly patients but patient conditions such as co-morbidity and injury severity, which can potentially affect the outcome of surgery in trauma patients, were not considered in the comparison (4).

Andersson et al. (3) retrospectively compared 11 single anterior screw fixations with 7 posterior techniques in elderly patients. They showed bone union in all patients 
treated posteriorly but only in 8 of 11 patients treated with single anterior odontoid screw fixation. They concluded that anterior screw fixation is associated with an unacceptably high rate of problems in the elderly patients. Smith et al., in a retrospective study, reviewed complications of anterior screw fixation (15 patients) with posterior approaches (60 patients) in a group of old patients. They found that length of hospitalization was not related to treatment and mortality was equivalent between these groups but postoperative complications were higher in anterior screw fixation patients. This study lacked clinical follow-up (21).

Drew et al. in (8) the study on 11 patients aged over 50 who had undergone surgery with posterior approach showed the mean operation time was 168 minutes and hospital stay was 16 days and all had uncomplicated. Yang Long noted in his report on 10 patients (mean age: 37.2 year) who had undergone surgery with anterior approach, the time of operation was 85 minutes and all had uncomplicated (22). Sai reported 48 patients (mean age: 41 years) who had undergone surgery with anterior approach. In this study, fusion rate was $96 \%$ and complication rate was $10 \%$ and hospital stay was 19.6 days (20). Kostas noted in his report on 50 patients (mean age: 47.7 years) who had undergone surgery with the anterior approach, fusion rate was $90.5 \%$ and there was no relationship between age and sex with rate of fusion (11). Susanna Anderson noted although it does not seem age and underlying disease are contraindication for surgery but mortality can be increased in elderly and patients admitted to hospital with severe underlying diseases (3).

The authors advocate of anterior approach for young patients because there is not severe restriction on neck movements in this approach $(11,40,20)$.

As we have shown in our study, the union rates in both anterior and posterior techniques are high (about 85\%) without any significant complications. Our patients were young adult and co-morbidity scores were not high, but there were no differences between injury severity and co-morbidity score between these two groups and it makes comparison between the surgical results in these patient groups more precisely. Our study showed that the duration of surgery in anterior approach was less than the posterior techniques and patients could experience less significant risk of surgery and general anesthesia. In addition, as described in literature, the rotational motion of neck is not affected with anterior screw fixation, in contrast to the posterior fixation that restricts significantly the cervical rotation. Therefore in many studies, the anterior approach is preferred as the first choice of surgical treatment in type II odontoid fractures.

The posterior techniques were preferred when there is any contraindication for the anterior fixation, including comminuting fracture of odontoid, fracture line from anterior inferior to posterior superior of base dens, ligament transverse rupture, non-reducible fractures, and nonunion cases longer than 3 months, cervicothoracic kyphosis, osteoporosis and patient body habitus compromise $(1,4,14,19)$.

\section{CONCLUSION}

In this study for the first time we compared the clinical result of surgery in patients with acute type Il odontoid fracture who are potential candidates for the both anterior and posterior approaches with considering pre-operative condition (injury severity score \& preinjury Charlson comorbidity index). Surgical management of type II odontoid fracture by both anterior and posterior approaches have shown good outcome in the patients who are potential candidates for surgery. In our patients, the operation time is different in the two groups but differences in fusion rate, length of hospital stay, comorbidity index and postsurgical complications are not considerable. According to this study, the anterior approach is a safe technique with union rate comparable to posterior approaches. It can be used as the first option in many patients with type II odontoid fractures. A long-term follow-up is needed to confirm highly precise results in these two groups.

\section{REFERENCES}

1. Aebi M, Etter C, Coscia M: Fractures of the odontoid process. Treatment with anterior screw fixation. Spine J 14:1065-1070, 1989

2. Anderson LD, D'Alonzo RT: Fractures of the odontoid process of the axis. J Bone Joint Surg 56(8):1663-1674, 1974

3. Andersson $S$, Rodrigues $M$, Olerud C: Odontoid fractures, high complication rate associated with anterior screw fixation in the elderly. Eur Spine J 9:56-60, 2000

4. Antonino A, Naale R, Nicola M, Roberto D: Treatment of remote type II axis fractures in the elderly, feasibility of anterior odontoid screw fixation. Neurosurgery 63:36-43, 2008

5. Apfelbaum Rl: Screw fixation of the upper cervical spine, Indications and techniques. Contemporary Neurosurg 16:1-8, 1994

6. Bednar D A, Parikh J, Hummel J: Management of type II odontoid process fractures in geriatric patients. A prospective study of sequential cohorts with attention to survivorship. Journal of Spinal Disorder 8:166-169, 1995

7. Bohler J: Anterior stabilization for acute fractures and non unions of the dens. J Bone Joint Surg Am 64:18-24, 1982

8. Chaudhary A, Drew B, Orr RD, Farrokhyar F: Management of type II odontoid fractures in the geriatric population; outcome of treatment in a rigid cervical orthosis. J Spine Disorder Tech 23(5):317-320, 2010

9. Coyne TJ, Fehlings MG, Wallace $\mathrm{MC}$, Bernstein $\mathrm{M}$, Tator $\mathrm{CH}$ : C1 - C2 posterior cervical fusion; Long - term evaluation of results and efficacy. Neurosurgery 37:688-692, 1995

10. De lure F, Donthineni R, Boriani S: Outcome of $C 1$ and $C 2$ posterior screw fixation for upper cervical spine fusion. Eur Spine J 18 (Suppl 1): s2 - s6, 2009

11. Fountas Kostas N, Machinis Theofilos G, Kapsalaki Eftychia Z: Surgical Treatment of Acute Type II and Rostral Type III Odontoid Fractures Managed by Anterior Screw Fixation. Southern Medical Journal 98(9):895-900, 2005

12. Fujii E, Kobayashi K, Hirabayashi K: Treatment in fractures of the odontoid process. Spine 13:694-699, 1998 
13. Hadley MN, Dickman CA, Browner CM, Sonntag VKH: Acute axis fractures; a review of 229 cases . J Neurosurgery 17: 642-648, 1989

14. Henry AD, Bohly J, Grosse A: Fixation of odontoid fractures by an anterior screw. J Bone Joint Surg 81:472-477, 1999

15. Jenkins J, Coric D, Branch C: A clinical comparison of one and two screw odontoid fixation. J Neurosurgery 89:366-370, 1998

16. Koivikko MP, Kiuru MJ, Koskinen SK, Myllynen P, Santavirta S, Kivisaari L: Fractures associated with nonunion in conservatively treated type - II fractures of the odontoid process. J Bone Joint Surg 86:1146-1151, 2004

17. Muller EJ, Schwinnnen I, Fischer K, Wick M, Muhr G: Non-rigid immobilization of odontoid fractures . Eur Spine J 12:522-525, 2003
18. Nakanishi T, Sasaki T, Tokita N Hirabayashi K: Internal fixation for the odotoid fracture. Orthop Trans 6:179-185,1982

19. Platzer P, Thalhammer G, Oberleitner G, Kutscha Lissberg $\mathrm{F}$, Wieland T: Surgical treatment of dens fractures in elderly patients. J Bone Joint Surg 89:1716-1722, 2007

20. Sai-Cheung L, Ji-Feng C, Shih-Tseng L: Management of acute odontoid fractures with single anterior screw fixation. Journal of Clinical Neuroscience 11:890-895, 2004

21. Smith HE, Vaccaro AR, Maltenfort M, Albert TJ, Hilibrand AS, Anderson DG, Harrop J: Trends in surgical management for type II odontoid fracture; 20 years of experience at a regional spinal cord injury center. Orthopedics 31:650-655, 2008

22. Yong-long C, XiangYang W: Management of odontoid fractures with percutaneous anterior odontoid screw fixation. Eur Spine J 16:1157-1164, 2007 